\title{
OBITUARIES
}

\section{Dr. Felix Oswald}

Dr. Felix Oswaxd, a distinguished geologist and archæologist, died on November 3 on the ninetysecond anniversary of his birth in 1866 .

After gaining the degree of B.A.(London), Oswald entered the Civil Service. In his spare time, however, he made a study of geology, botany and zoology, and eventually presented these as his subjects for the B.Sc. degree examination, London, in which he gained first-class honours.

In 1898 he accompanied N. B. Lynch as geologist on a tour through Turkish Armenia. On their arrival at Lake Van, he made a careful investigation of the rocks and structure of the Crater of Nimrud, a volcano on the west shore of the lake. He later wrote "The Geology of Armenia" and presented it as his thesis for the degree of D.Sc.(London). As the cost of providing the requisite number of copies for the examiners proved prohibitive, he set up a press and printed 200 copies himself. The book had 600 pages and a number of coloured illustrations. $\mathrm{H}_{\theta}$ also made a geological map of Armenia and a coloured relief model of the Crater on the scale of 1 in. to the mile.

In 1907 he was elected a Fellow of the Geological Society of London. He also received from the Council of the Society an award from the Murchison Fund in recognition of his work in Armenia. In 1911 he went to Central Africa, on behalf of the British Museum, to investigate fossiliferous beds of Mid-Tertiary Age that had been discovered northeast of Victoria Nyanza. Four years later he was sent to the Caucasus in response to a request from the Russian Government for a geologist to search that region for additional sources of oil. In this work he was successful, and in addition produced a geological map of the Caucasus mountains.

Meanwhile, Oswald was appointed probate registrar for the Fast Midlands and accordingly moved to Nottingham. Here he became interestod in Margidunum, a Roman station situated on the Fosseway. About 1911 he started excavating the site and continued until his retirement, in 1936, to Solva in Pembrokeshire. He built up a remarkable collection of pottery from the site. This is now housed in the museum of the University of Nottingham. $\mathrm{He}$ visited every important collection of Roman pottery in Europe. With the unrivalled knowledge thus gained, he produced several magnificent works on terra siggillats and many small ones, including detailed accounts of Margidunum. $\mathrm{He}$ won an international reputation, and even during his long retirement was visited and consulted by scholars from many parts of the world.

\section{H. H. SWINNERTON}

\section{Dr. Francisco Duran-Reynals}

THE death of Dr. F. Duran-Reynals, which occurred on March 27, 1958, deprived experimental pathology of one of its outstanding figures. Apart from many well-known studies of the role of viruses in the etiology of cancer, I particularly wish to record Duran-Reynals's influence-not so widely appreciated -in stimulating this field over many years less directly, and in encouraging developments which in turn have facilitated recent dramatic advances, particularly in the United States, in our knowledge of tumour viruses.

Francisco Duran-Reynals was born in Barcelona on December 5, 1899. After graduating from the University of Barcelona as M.D. in 1925, he then spent three years in work at the Pasteur Institute in Paris (with Profs. A. Besredka and E. Wollman), and (with Dr. J. B. Murphy) at the Rockefeller Institute, New York, to the staff of which he was appointed in 1928 . In 1938, he became research professor at Yale University School of Medicine, with support from the Jane Coffin Childs Memorial Fund for Medical Research.

Duran-Reynals's earlier work was mainly concerned with the so-called ground-substance of the mesenchyme, and arose from the discovery of spreading factors-hyaluronidase and others-in mammalian testes (1928), bacteria (1933), snake venom (1936), and many other sources. His studies of viruses in relation to cancer date from 1938, and were continued to the end of his life, with much assistance from his wife, M. L. Duran-Reynals. These studies bore specially upon such aspects as virus variation and adaptation, antigenicity and epidemiology, and an important observation (of particular interest in relation to more recent discoveries) was of their maximal infecting power when injected into immature hosts.

Duran-Reynals was the recipient of many honours, notably (in 1952) the Anna Fuller Memorial Prize for Medical Research. His contributions not only to the above problems but also to many others in experimental pathology are embodied in upwards of a hundred papers, the last (1958) being a study of the infectious pulmonary adenoma complex in sheep.

In all he did he was not only scientist but artist as well. None who had the privilege to know him will soon forget his endearing qualities, his courage and gaiety, or his love of his native Spain.

A. HaDDow

\section{Dr. R. C. Fisher}

Dr. Ronald CAMPBell Frsher was born on August 6, 1899, at Edinburgh, and died unexpectedly in his sleep on October 23. He was the elder son of Archibald W. Fisher, solicitor, and Catherine Dick Fleming. From George Heriot's School he proceeded to the University of Edinburgh, where he graduated in forestry in 1921 and was awarded the medals for advanced forestry and forest zoology. Following studies at Kew and Rothamsted on a research scholarship awarded by the Ministry of Agriculture and Fisheries, he received his doctorate for a thesis on forest insects in 1923.

After working for two years at the Imperial Forestry Institute, Oxford, Fisher transferred to the Forest Products Research Laboratory (Department of Scientific and Industrial Research) at Princes Risborough, as the first officer-in-charge of the Fintomology Section. At that time, little was known of timber-boring insects in Great Britsin, but during the thirty-one years he was in charge of this work, 